\title{
Role of stem cells in revascularization of necrotic permanent teeth with immature apex
}

\section{Introduction}

This work has been collected from some endodontics text books, researches, and inrenet to make a complete story concerning pulp revasculariaztion.

Stem cells differ from other kind of cells in the body. They found in most, if not all, multi-cellular organisms. They are undifferentiated cells characterized by the ability to renew themselves through mitotic cell division and differentiating into a diverse range of specialized cell types. The two types of mammalian stem cells are: embryonic and adult stem cells. Stem cells are harvested from:

1. Blastocyst (embryoblasts).

2. Amniotic fluid.

3. Umbilical cord in newborns.

4. Red marrow in the crest of the ilium by aspiration.

5. Hair follicle bulge.

6. By administration of certain drugs that stimulating the release of stem cells from the bone marrow into circulating blood (similar to donating blood).

\section{Cleavage stages (Figure I-3)}

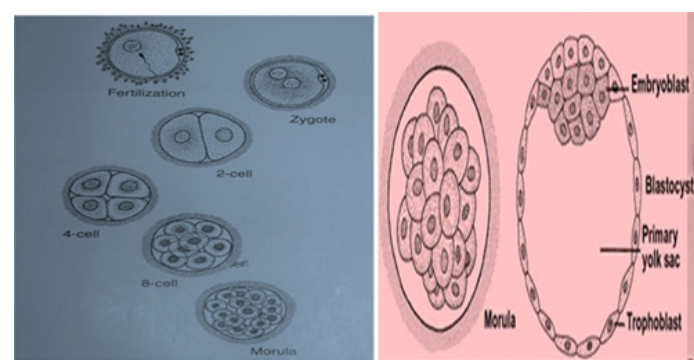

Figure I Cleavage stages.

Morula $\longrightarrow$ Blastocyst $\longrightarrow$ Embryoblasts + Trophoblasts

Embryoblasts considered the best Set Cell

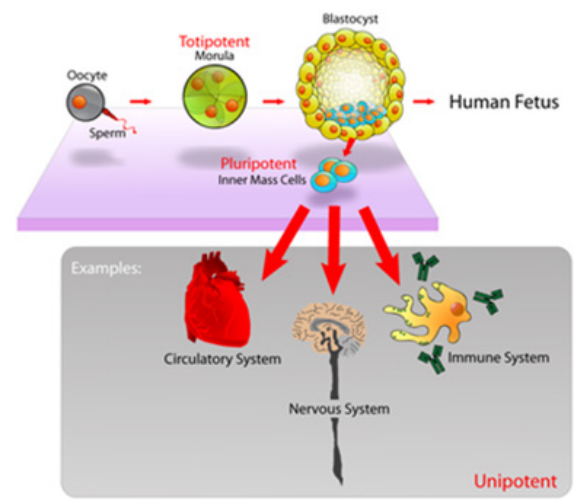

Figure 2 Pluripotent, embryonic st. cs. originate as inner mass cells within a blastocyst. They can become any tissue in the body, excluding a placenta.
Volume 6 Issue 6 - 2017

Abdelhamied Y Saad

Department of Dental Sciences, King Saud University, Saudi Arabia

Correspondence: Abdelhamied Y Saad, Department of Dental Sciences, Professor of Endodontics, College of Dentistry, King Saud University, Saudi Arabia,

Email dr.abdelhameed@hotmail.com

Received: March 28, 2016| Published: April 07, 2017

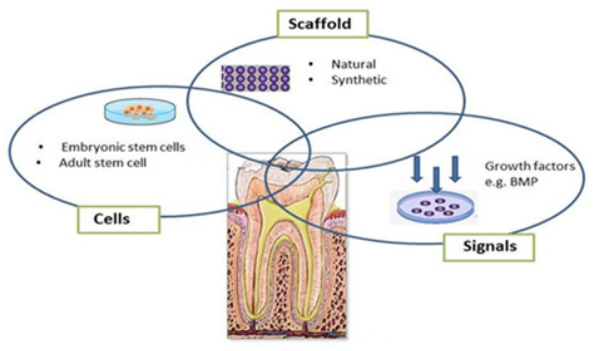

Figure 3 Triad of tissue Engineering.

A. To date, only case reports on endodontic revascularization treatment are available.

B. Nearly all the reported cases involve patients. From 8 to 18 years old with necrotic teeth and immature apices.

C. Younger patients have a greater healing capacity or stem cells regenerative potential.

D. Open apex may foster the ingrowth of periapical tissue into the $\mathrm{RC}$ space.

E. This tissue may represent a rich source of mesenchymal stem cells coming from the apical papilla.

F. Laceration of this papilla will deliver mesenchymal stem cells into the RC space (Figure 4).

\section{Materials and methods}

Aim of the study: Was to develop a tissue engineering-based method of pulpal regeneration in the incompletely developed permanent teeth that has an open apex and necrotic pulp

\section{Protocol for revascularization treatment}

\section{At the first appointment (Figure 5)}

a. Tooth was anesthetized, isolated, and accessed. 
b. Minimal instrumentation using small file was performed and the W. L. was determined.

c. Copiouse and slow irrigation with $\mathrm{NaOCl}$ followed by chlorhexidine (use Max-I-Probe needle- hasclose end and sideport vents (Figure 6).

d. The canal was then dried and antimicrobial medicament was delivered into the canal such as a "Triple Antibiotic Paste" or $\mathrm{Ca}(\mathrm{OH}) 2$.

\section{$1: 1: 1$}

Ciprofloxacin: metronidazole: minocycline (Figure 7)

The tooth was then sealed with a sterile cotton pellet and Cavity and the patient is discharged for 3 to 4 weeks.
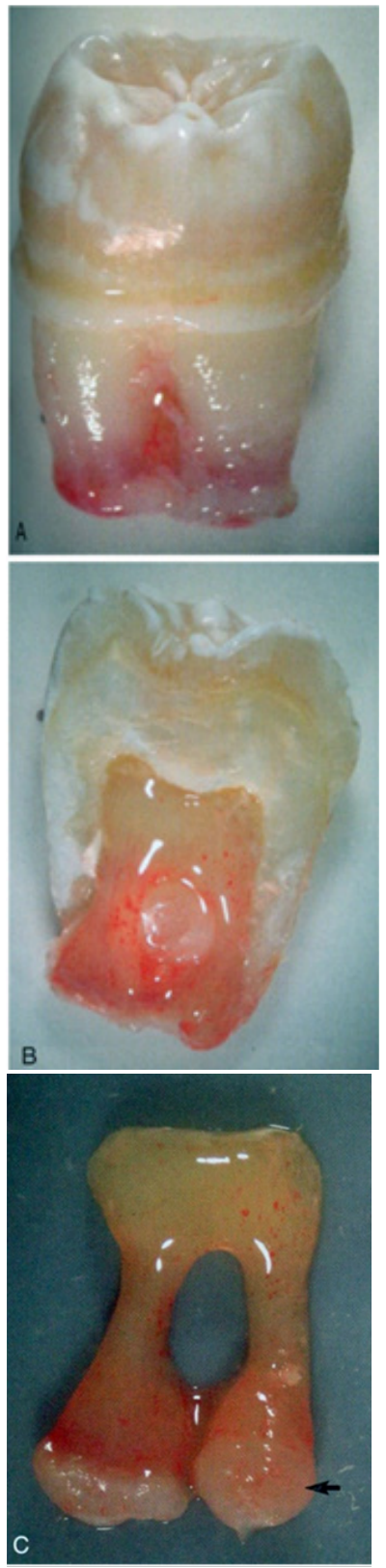

Figure 4 Dissection of an immature permanent tooth indicating the extent of the apical papilla.

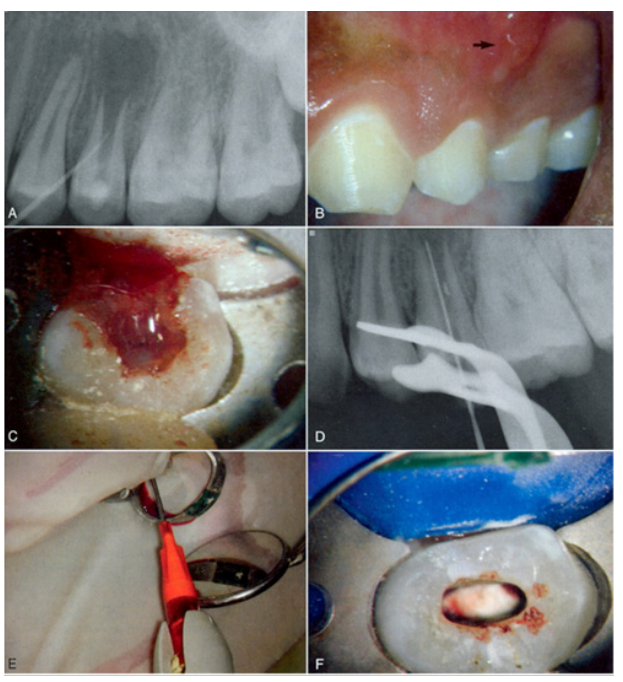

Figure 5 First appointment.
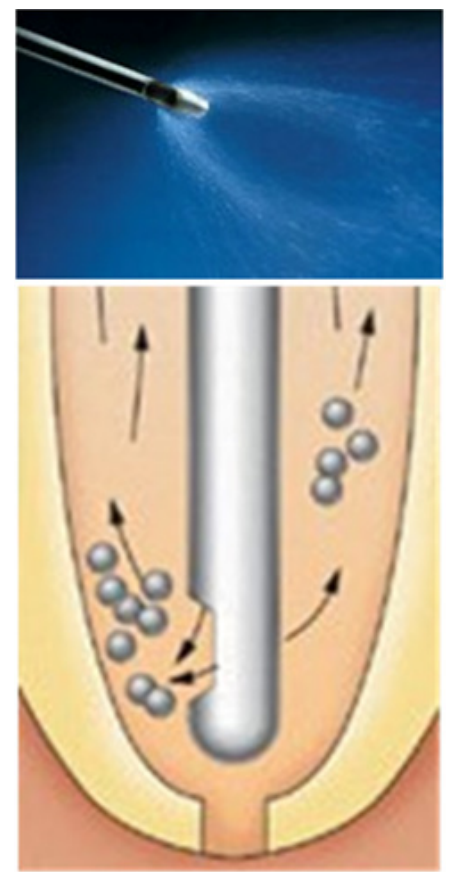

Figure 6 Maxi-I-Prob needle, irrigate through side vents (Douching spray reaches all regions by rotating needle)

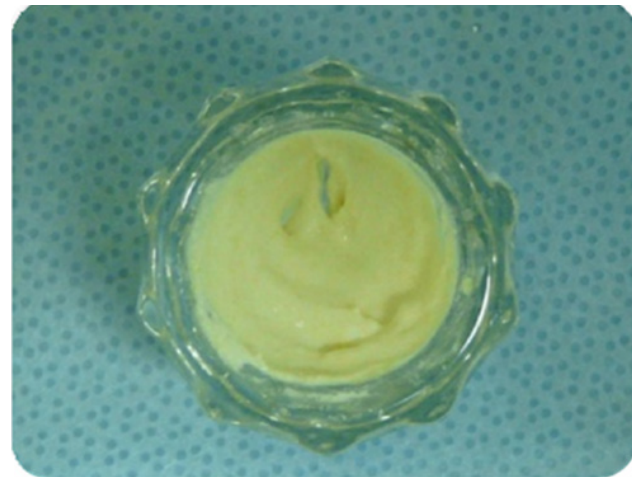

Figure 7 Triple antibiotic. 


\section{At the second appointment (Figure 8)}

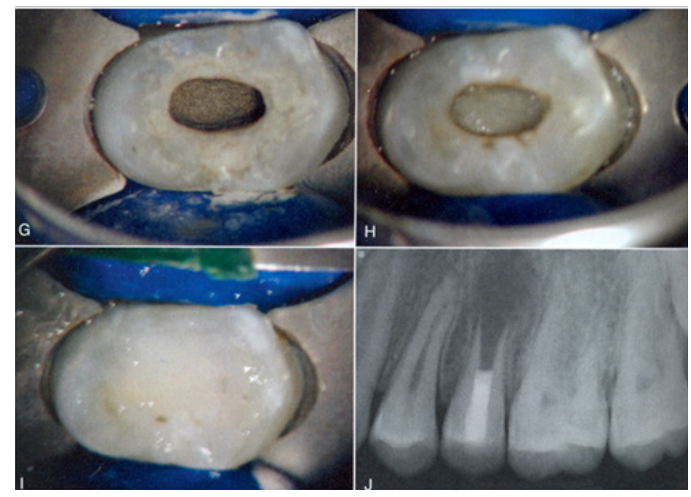

Figure 8 Second appointment.

a. Evaluate the patient for resolution of any signs or symptoms of an acute infection (e.g. pain, swelling, sinus tract, etc.).

b. Repeat the antimicrobial treatment if resolution has not occurred.

c. Anesthetized the tooth with vasoconstrictor free local anesthetic (3\% mepivacaine) to trigger bleeding into the RC system.

d. Isolate, access, and copiously and slowly irrigate with $\mathrm{NaOCl}$ and $17 \%$ EDTA and then a final flush with saline with gentle agitation using a small file to remove the medicament (Figure 9).

e. Dry the canal, place a file a few $\mathrm{mm}$ beyond the apical foramen and lacerate the apical tissue with bleeding up to $3 \mathrm{~mm}$ from the CEJ.

f. Repeat the antimicrobial treatment if resolution has not occurred.

g. Insert a small piece of Colla Cote into the canal to serve as a resorbable matrix to restrict the positioning of $3 \mathrm{~mm}$ of the MTA.

h. Restore the tooth and recall up to 12 to 18 months (or up to 36 months to demonstrate continued root development).

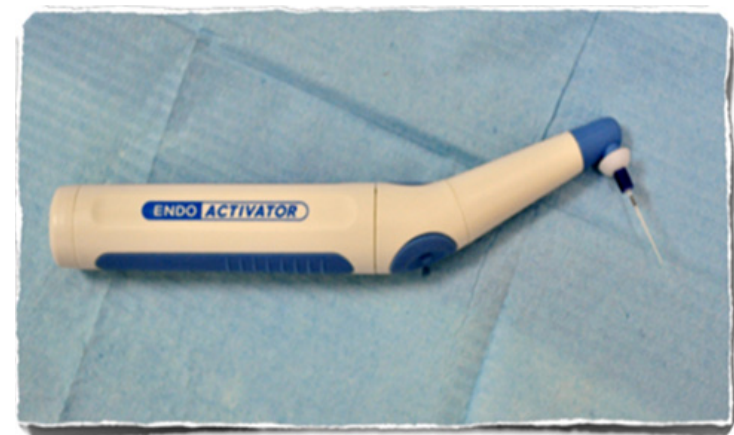

Figure 9 Endo Activator used to agitate $\mathrm{NaOCl}$.

\section{Results}

\section{Nearly all cases showed}

I. Continued apical healing

II. Thickening of root walls
III. Apical closure

IV. Increased root length

\section{Case I}

Lower right 2nd premolar (Figure 10-14).

$\mathrm{WL}+$ irrigation + Triple antibiotic paste + Cavit (Dismiss the Pt. for 3 weeks).

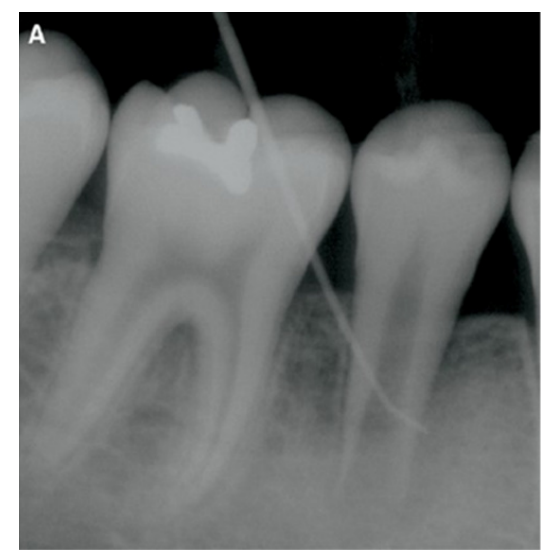

Figure 10 Incompletely developed apex and a periradicular radiolucency.

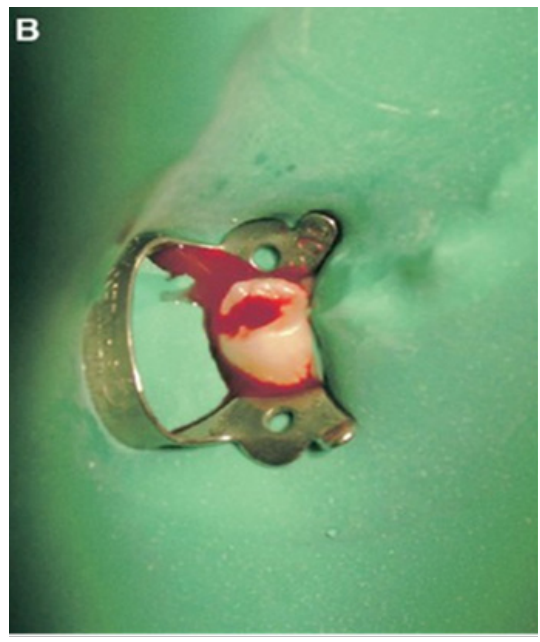

Figure I I A purulent hemorrhagic exudate discharged from the tooth.

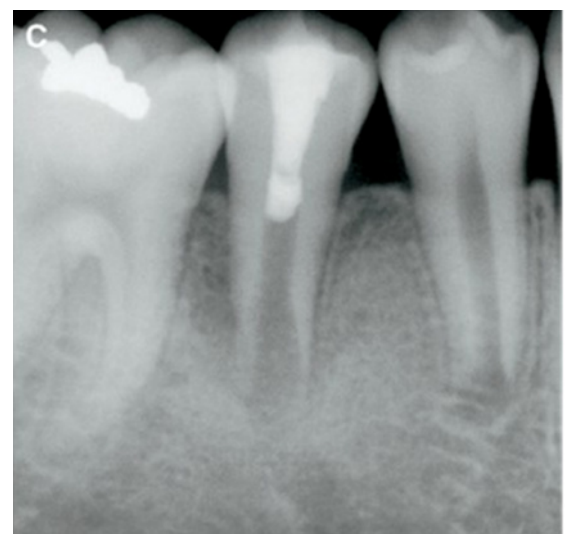

Figure 12 Placement of MTA and tooth restored following bleeding. 


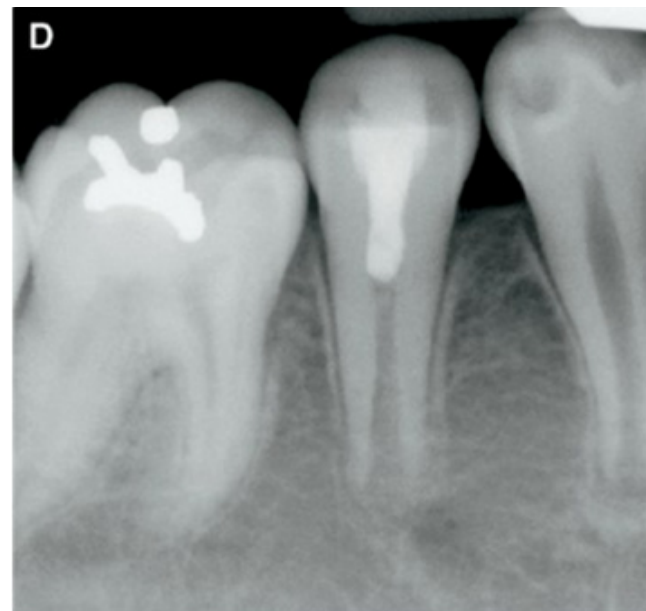

Figure I 3 Three-month recall radiograph (A slight increase in root thickness and continued apex development).

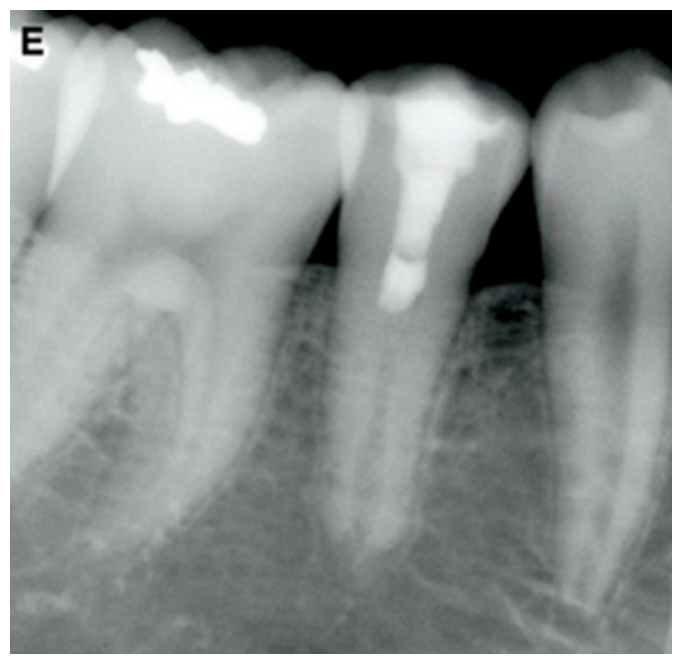

Figure I 4 Two-year radiograph showing continued root development.

\section{Case 2}

(Figures 15-19) WL + irrigation + Triple antibiotic paste + Cavit (Dismiss the Pt. for 3 weeks).

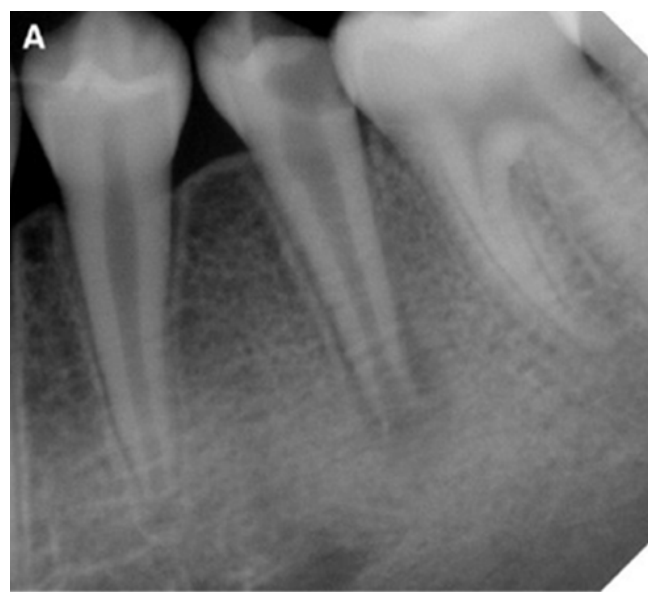

Figure 15 Incompletely developed apex and a periradicular radiolucency.

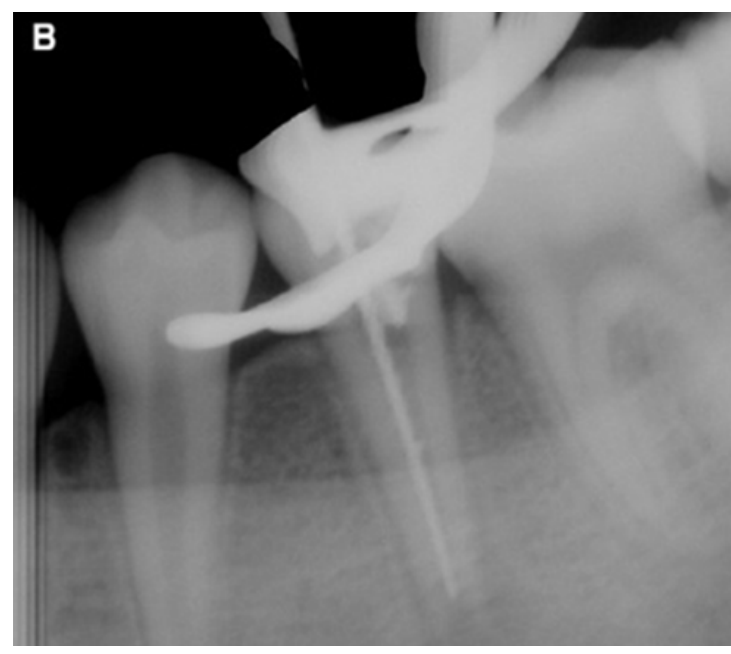

Figure I6 K-file introduced into the canal without anesthesia.

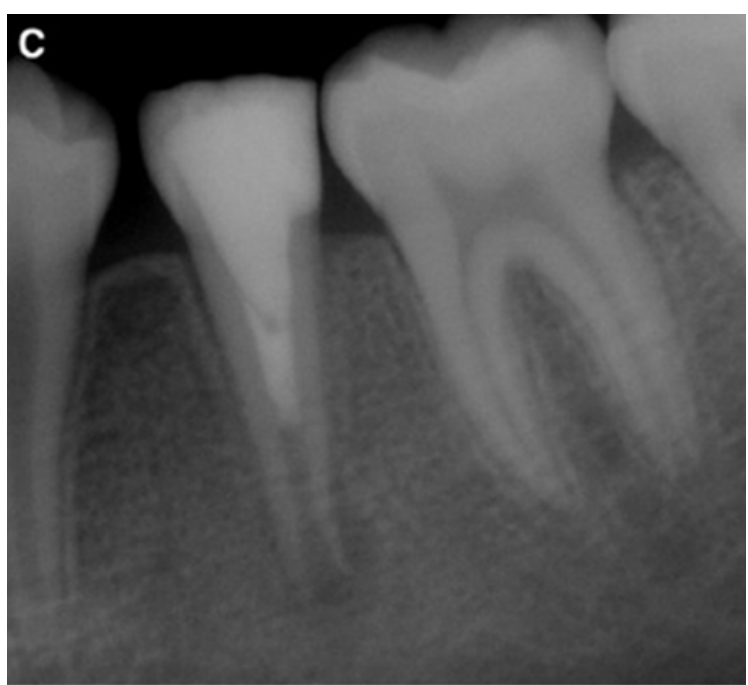

Figure I 7 MTA carefully placed over the blood clot followed by wet cotton pellet and Cavity.

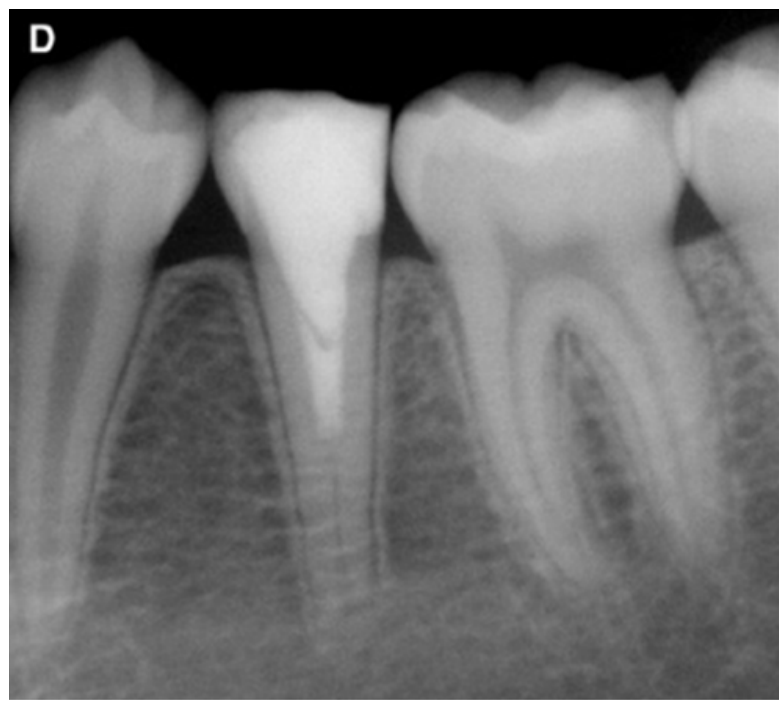

Figure 18 Twelve-month radiograph showing complete resolution of the radiolucency and a calcification of the canal space. 


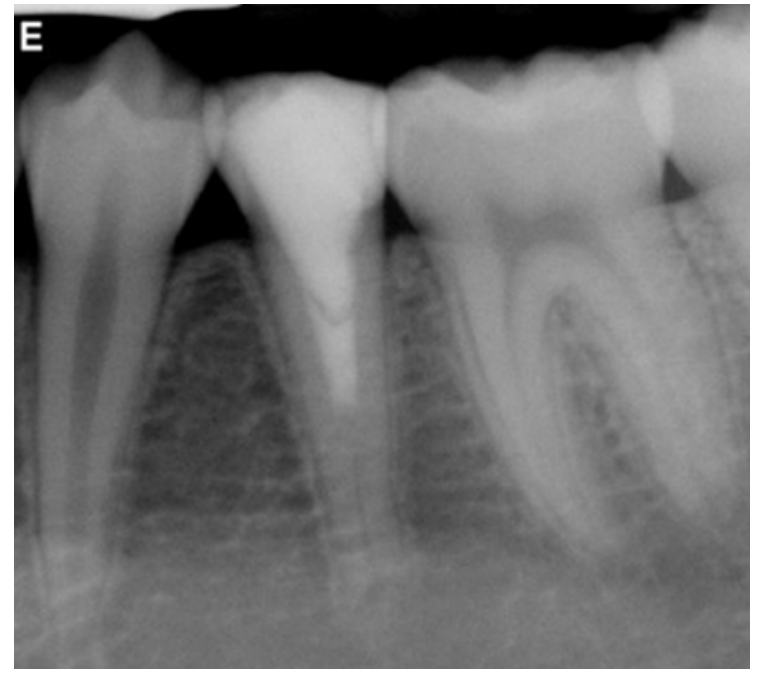

Figure 19 Two-year follow-up radiograph showing excellent healing.

\section{Case 3}

8 years old female (Figures 20-22).

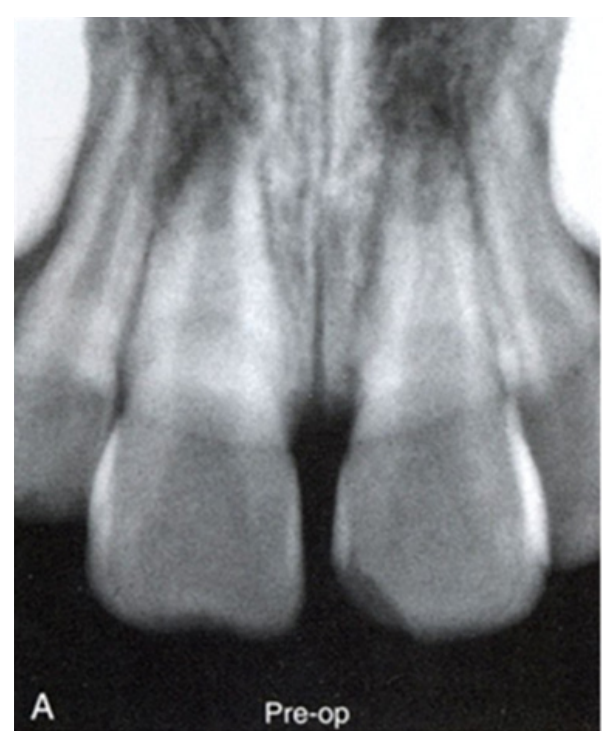

Figure 20 Necrosis (Trauma).

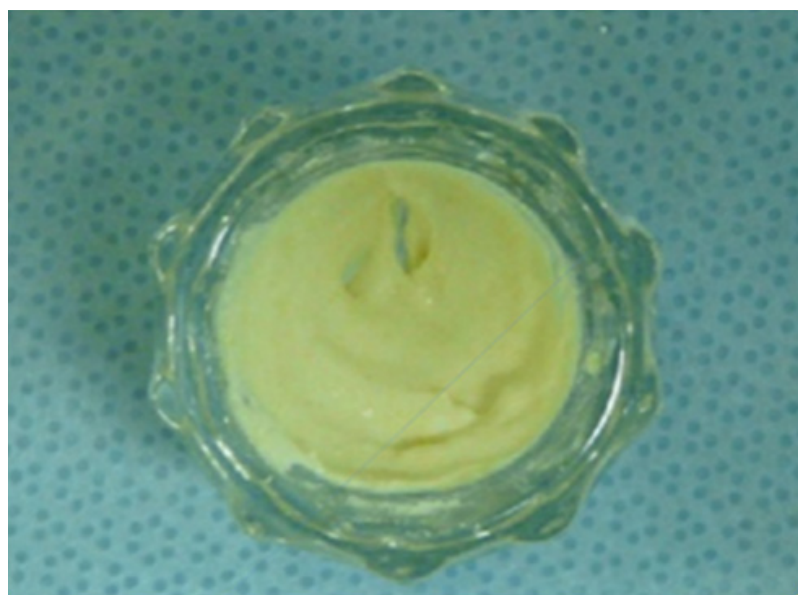

Figure 2I Triple antibiotic.

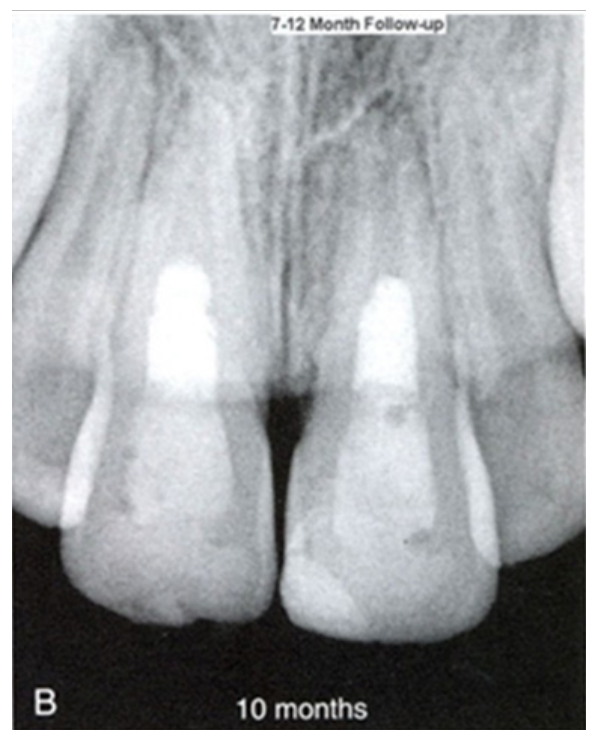

Figure 22 Sealing with white MTA and composite restoration.

\section{Case 4}

(Figures 23-27).

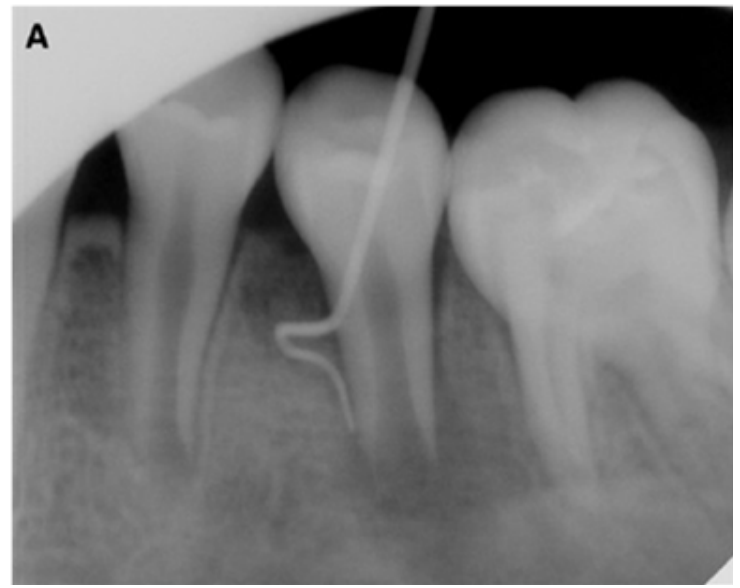

Figure 23 Periradicular radiolucency associated with lower 2nd premolar.

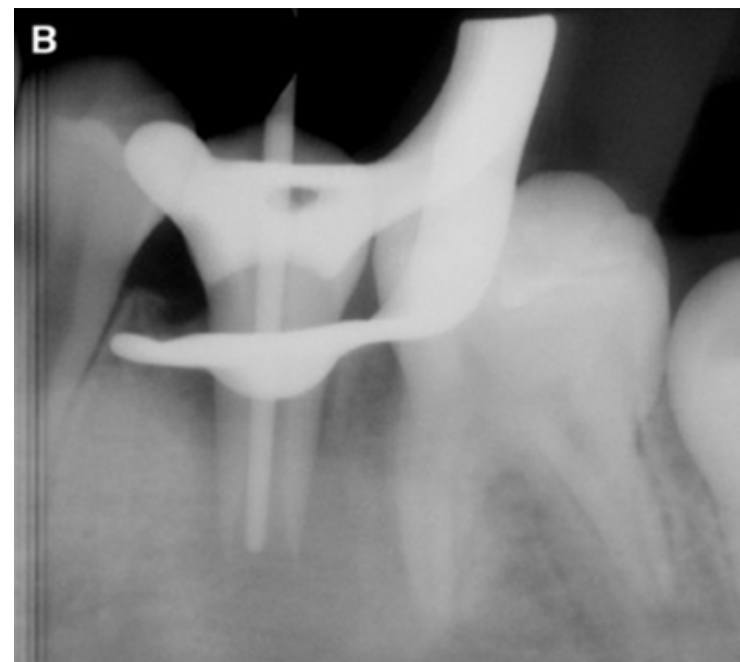

Figure $24 \mathrm{~A}$ gutta-percha cone can be introduced into the canal easily.

Citation: Saad AY. Role of stem cells in revascularization of necrotic permanent teeth with immature apex.J Dent Health Oral Disord Ther. 2017;6(6):190-202. DOI: 10.15406/jdhodt.2017.06.00222 


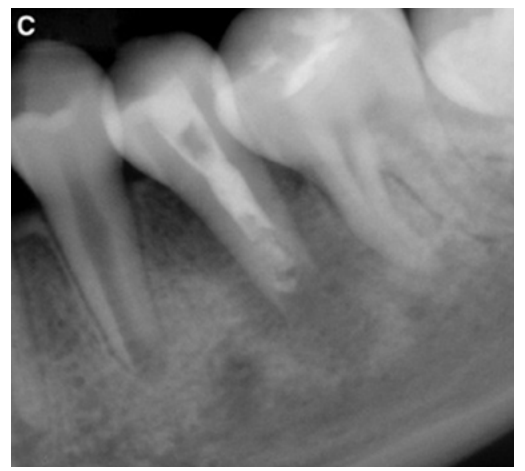

Figure 25 Placement of MTA and tooth restored.

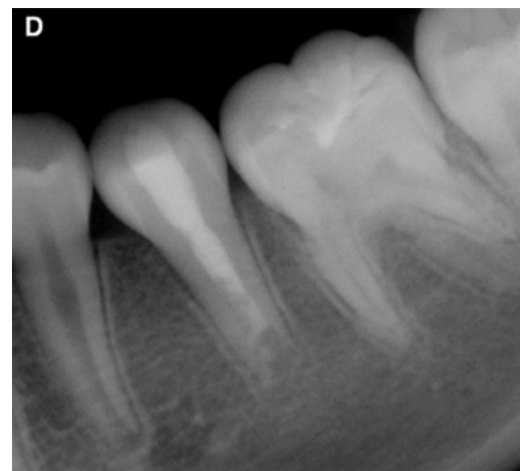

Figure 26 Six-month recall radiograph. The radiolucency has disappeared with continued root development.

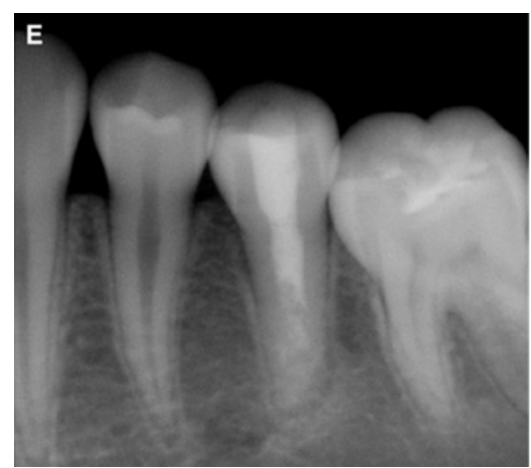

Figure 27 Thickening of the dentinal walls and closure of the apex. Case 5

(Figures 28-31)

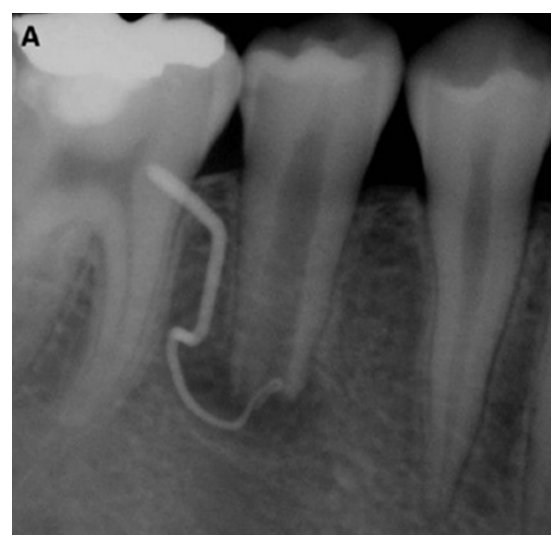

Figure 28 Periradicular radiolucency associated with lower 2nd premolar.

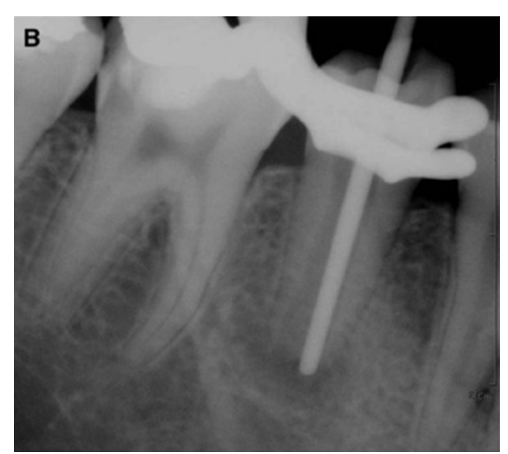

Figure 29 A gutta-percha cone can be introduced into the canal easily.

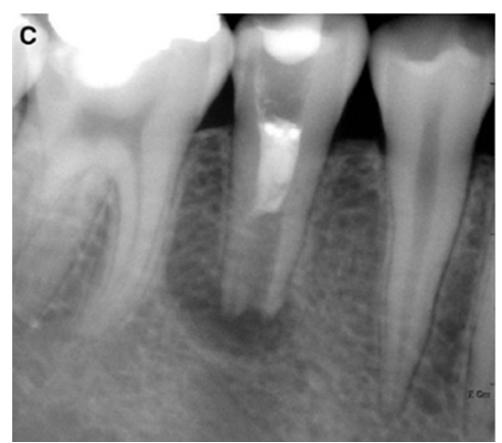

Figure 30 MTA placed over the blood clot followed by a wet cotton pellet and cavity.

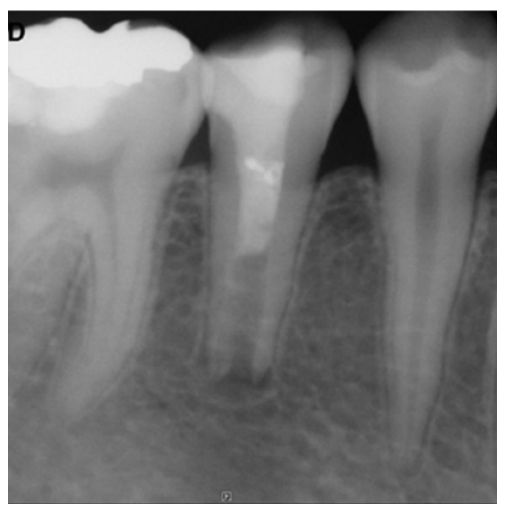

Figure 3 I One-yr follow-up reduced periradicular radiolucency.

\section{Case 6}

(Figures 32-34).

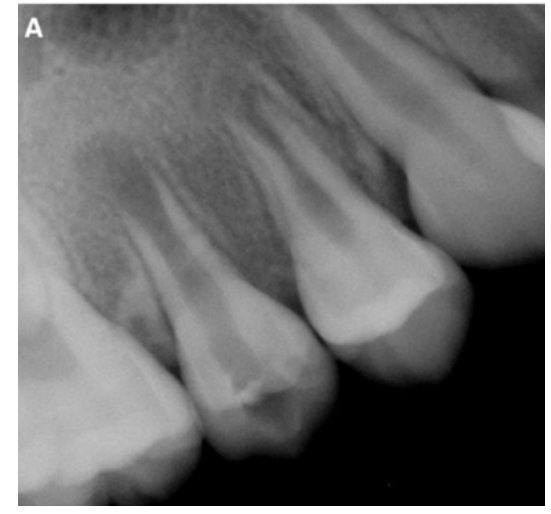

Figure $32 \mathrm{~A}$ periradicular radiolucency around the incompletely formed apex.

Citation: Saad AY. Role of stem cells in revascularization of necrotic permanent teeth with immature apex.J Dent Health Oral Disord Ther. 20I7;6(6): 190-202. DOI: 10.15406/jdhodt.2017.06.00222 


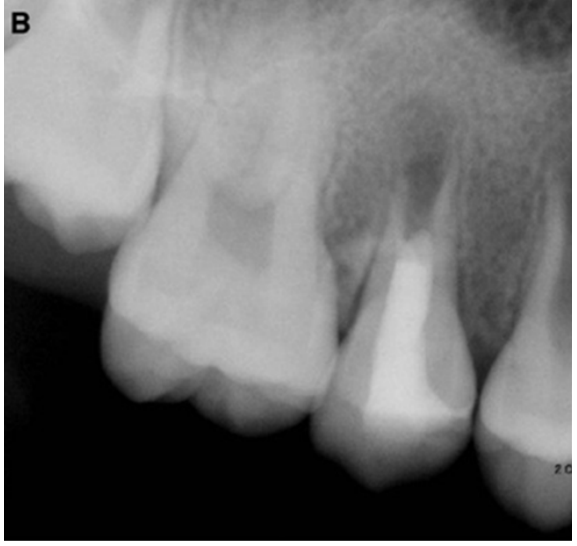

Figure 33 MTA carefully placed over Collatap followed by a wet cotton pellet and Caviton.

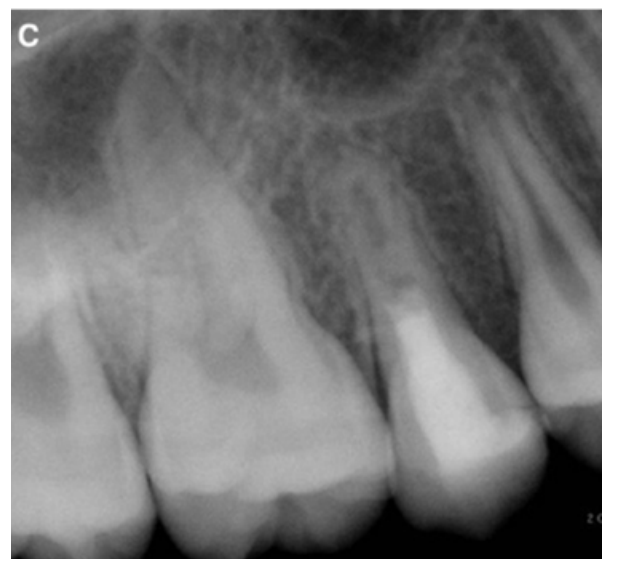

Figure 34Completeresolution of theradiolucency withcontinuedapicalclosure.

17 month follow up.

\section{Case 7}

An 8-years-old girl (Figures 35-40).

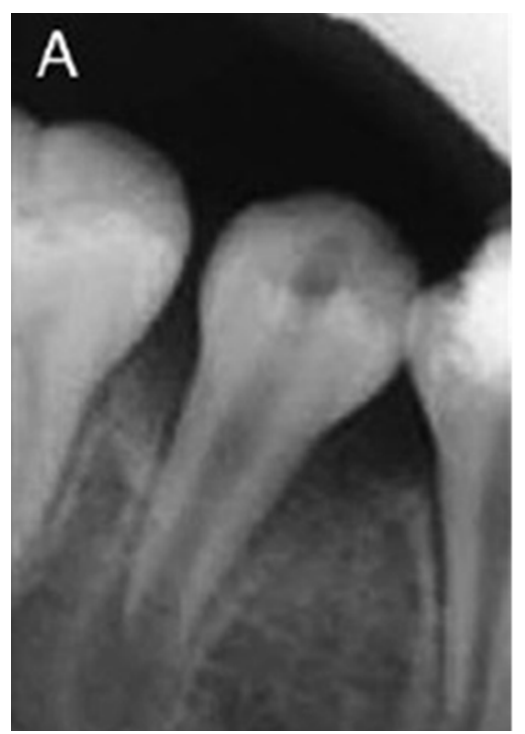

Figure 35 Fractured dens invaginatus premolar with acute periapical infection with wide canal and open apex.

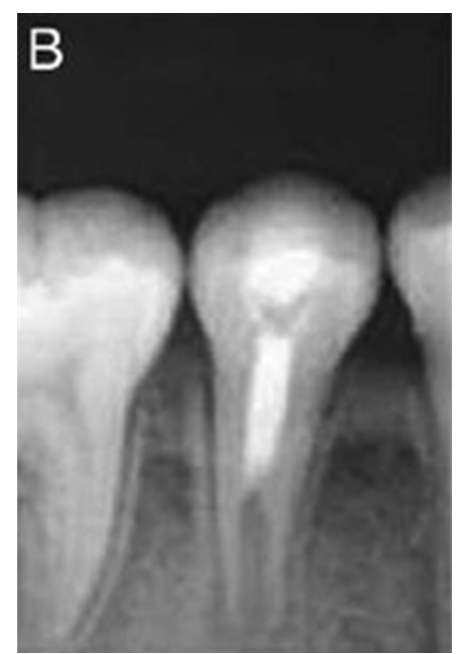

Figure 36 Three months after revascularization, elongation of the root was evident.

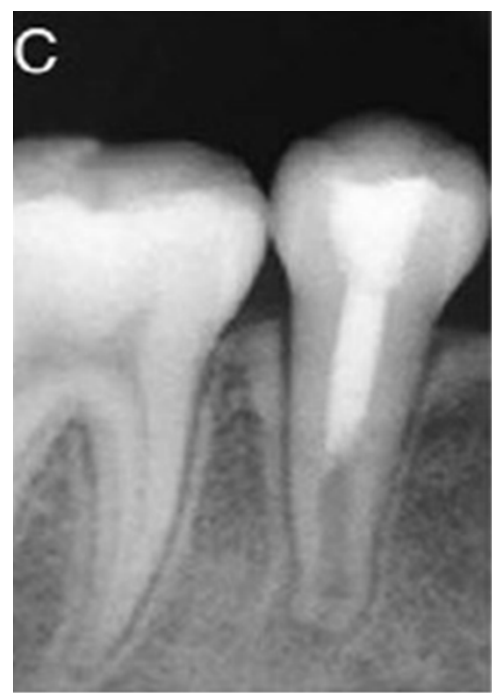

Figure 37 Thickening of dentinal walls and root lengthening were discernible.

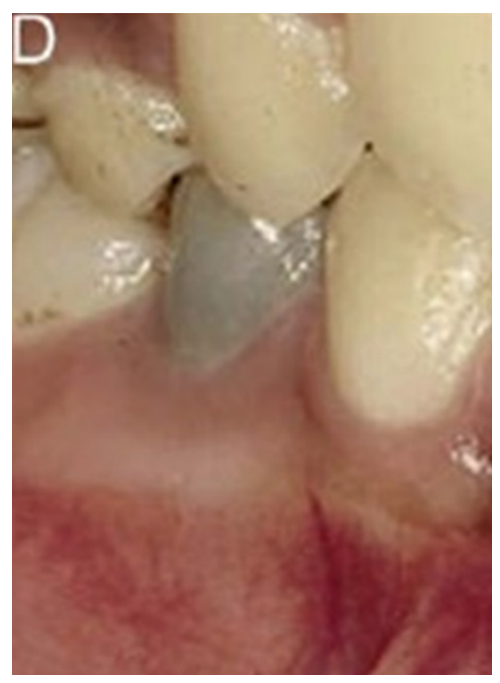

Figure 38 Photograph showing tooth discoloration.

2-month follow-up. 


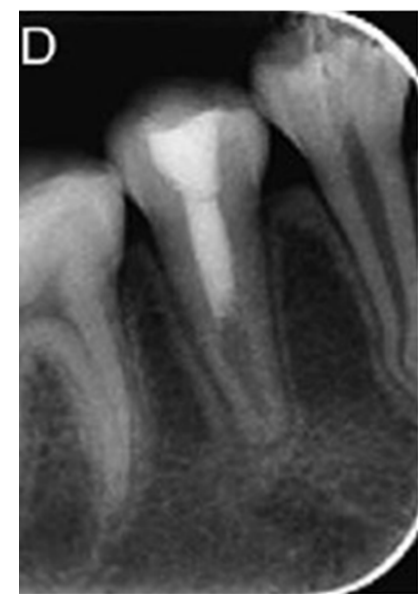

Figure 39 Further narrowing of root canal with normal bony architecture at the periradicular region.

I8-month follow-up.

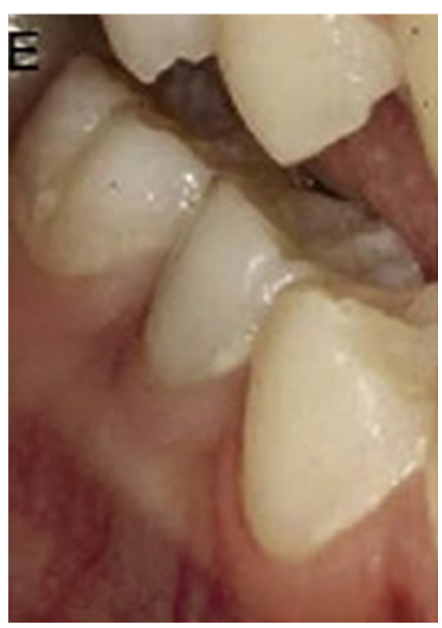

Figure 40 Photograph showing normal alveolar gingiva and mucosa. 18- Months follow-up (after bleaching).

\section{Case 8}

(Figures 41-43).

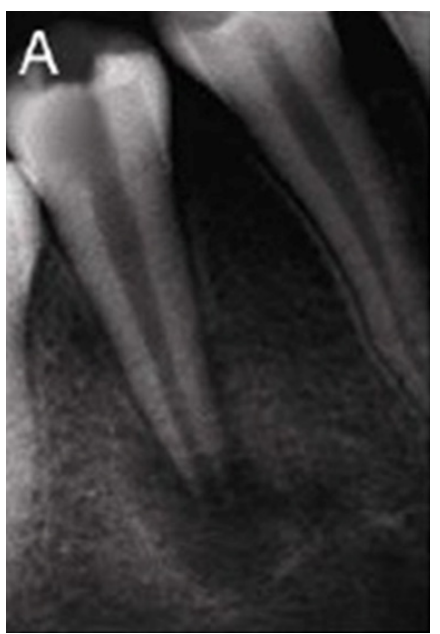

Figure 4I Open apex with a well defined radiolucency. 9.5-years-old girl.

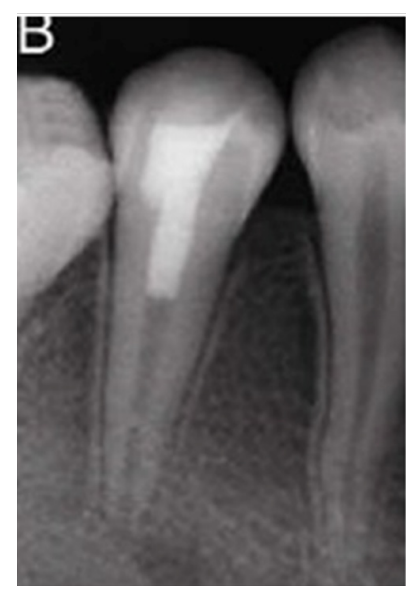

Figure 42 Disappearance of the periapical lesion and narrowing of the apex. $6 \mathrm{~ms}$.

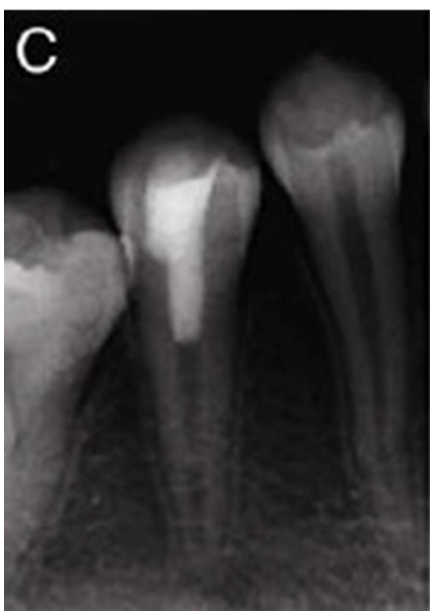

Figure 43 Apical closure and normal periradicular architecture. $15 \mathrm{~ms}$.

\section{Case 9}

14-years-old female pulp necrosis (Dens) (Figures 44-46).

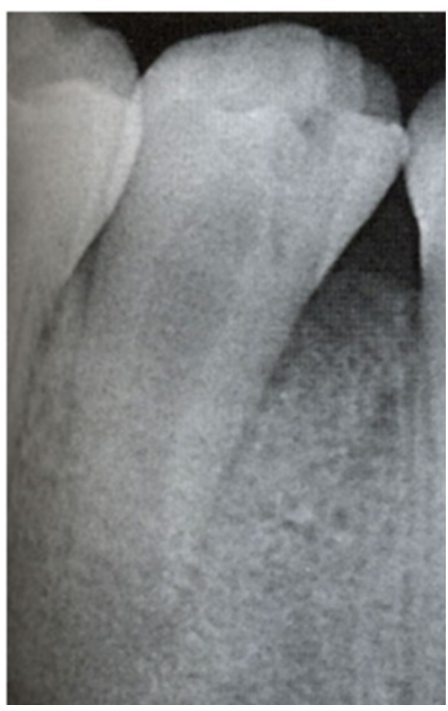

Figure 44 Pre-operative.

Citation: Saad AY. Role of stem cells in revascularization of necrotic permanent teeth with immature apex.J Dent Health Oral Disord Ther. 2017;6(6):190-202. DOI: 10.15406/jdhodt.2017.06.00222 


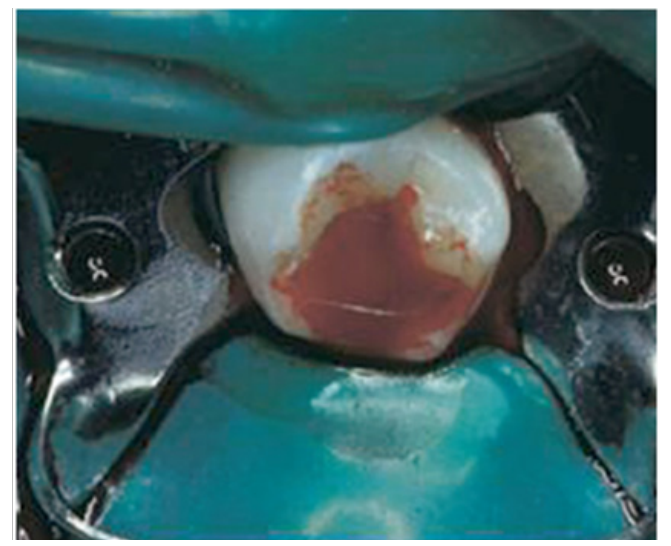

Figure 45 Purulent hemorrhagic exudates discharged from the tooth.

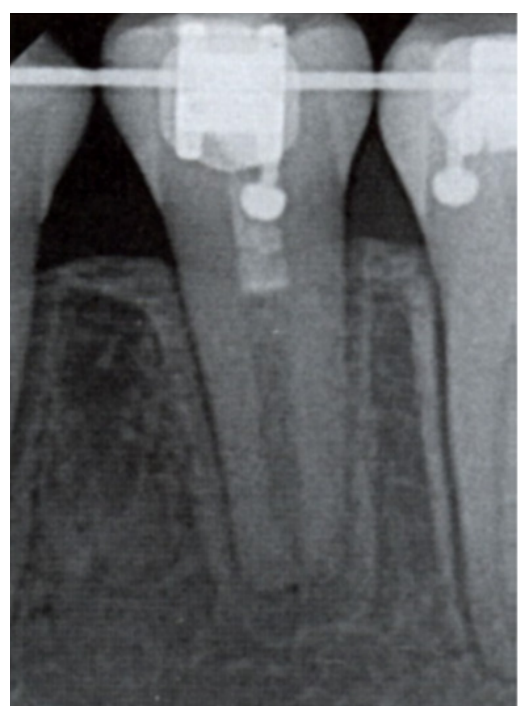

Figure 46 Bleeding was established, and RC system was sealed with MTA and a composite restoration.

Three years.

\section{Case 10}

(Figures 47 \& 48).

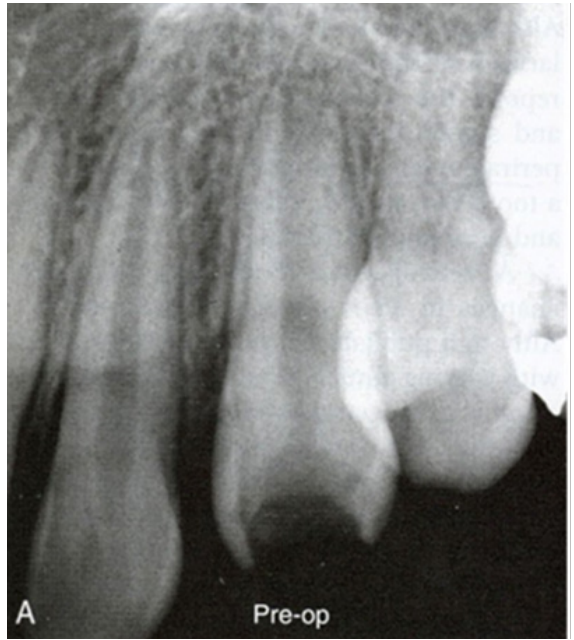

Figure 47 Pre-operative.

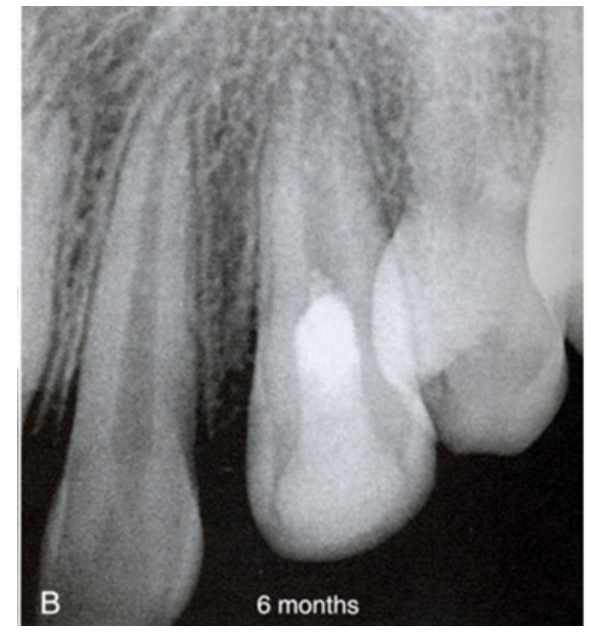

Figure 486 months.

\section{Case | |}

(Figures $49 \& 50$ ).

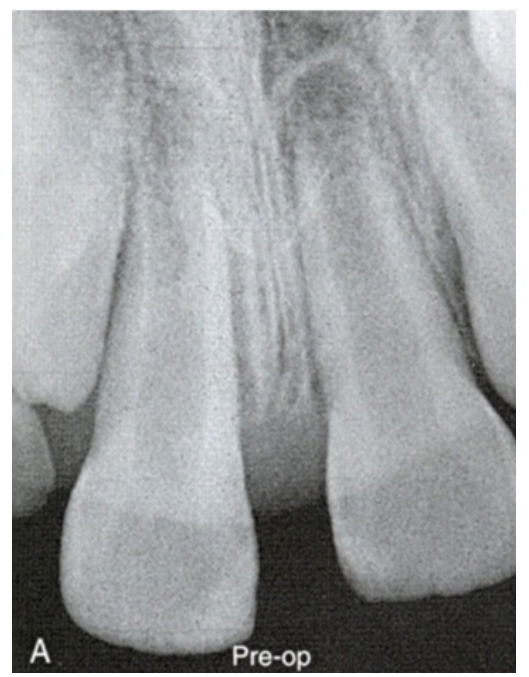

Figure 49 Pre-operative.

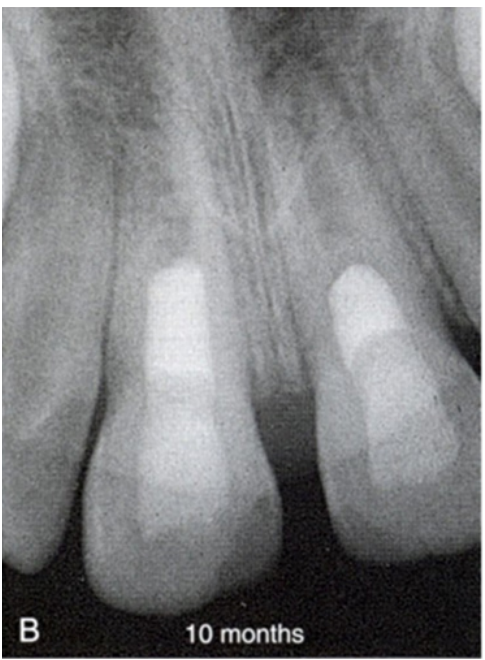

Figure 5010 months.

Citation: Saad AY. Role of stem cells in revascularization of necrotic permanent teeth with immature apex.J Dent Health Oral Disord Ther. 2017;6(6): 190-202. DOI: 10.15406/jdhodt.2017.06.00222 


\section{Case I 2}

Pulpotomy initiated (Figures 51-56).

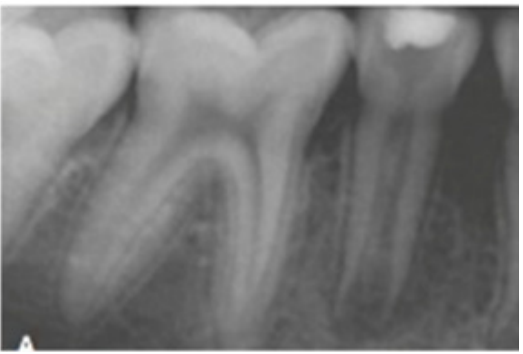

Figure 5 I Trauma - pulp necrosis. Lower right $2^{\text {nd }}$ premolar. 9-years-old female.

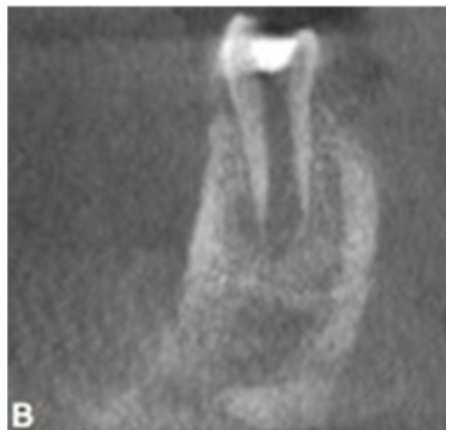

Figure $52 \mathrm{CBCT}$ (Double antibiotic past).

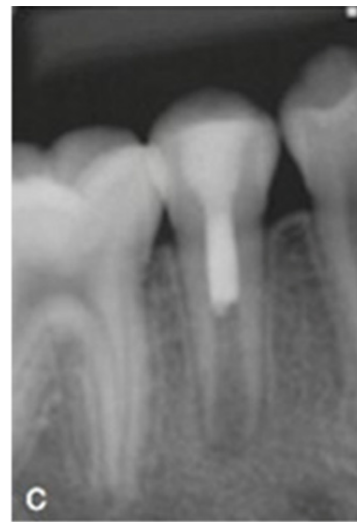

Figure 53 Bleeding + Collaplug + MTA + composite.

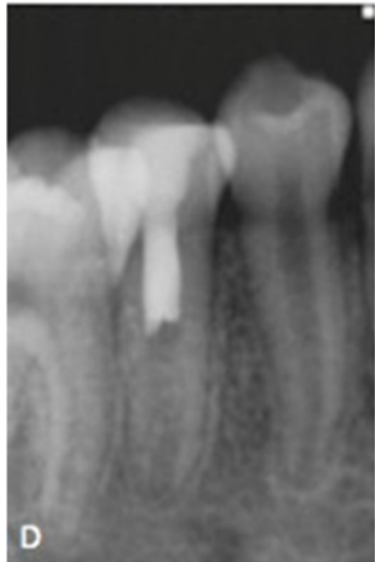

Figure 54 Five month recall.

Figure 56 Greater root maturation (2.5-yr recall).

Citation: Saad AY. Role of stem cells in revascularization of necrotic permanent teeth with immature apex.J Dent Health Oral Disord Ther. 2017;6(6): 190-202. DOI: I0.15406/jdhodt.2017.06.00222 


\section{Case I 3}

8-years-old girl (Figures $57 \& 58$ ).

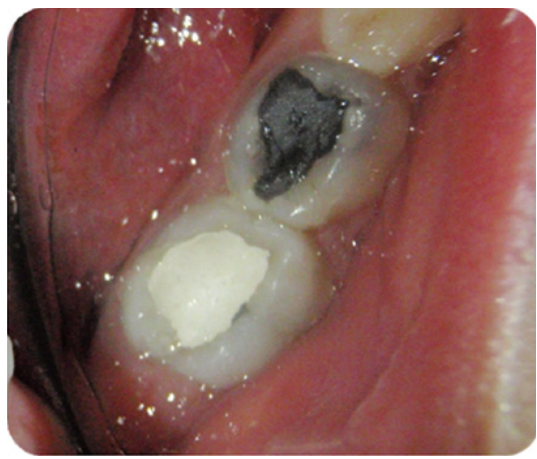

Figure 57 Pulpotomy was initiated 3 weeks earlier referred to complete endo treatment.

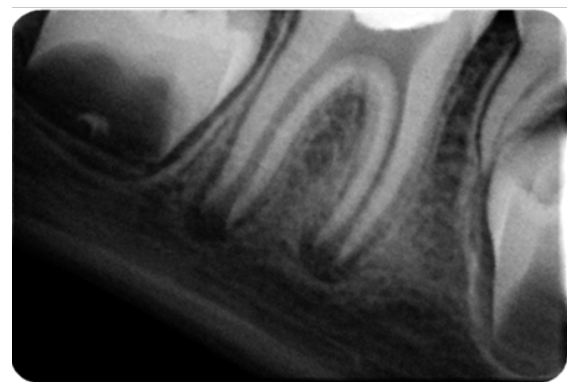

Figure 58 Open apex.

$\mathrm{WL}+$ irrigation + Double antibiotic paste + Cavit (Dismiss the Pt. for 3 weeks).

Canals disinfection (Figure 59).

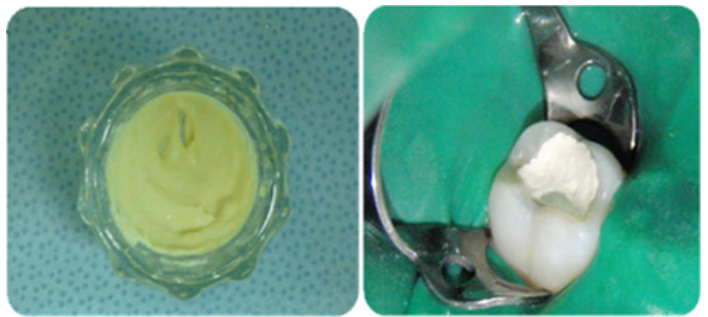

Figure 59 Triple antibiotic.

Bleeding initiated (Figure 60).

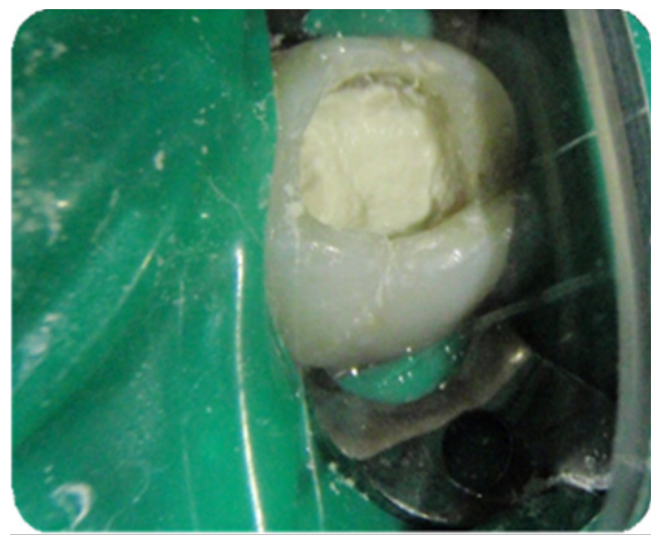

Figure 60 MTA barrier.
MTA barrier (Figure 61, 62-64).
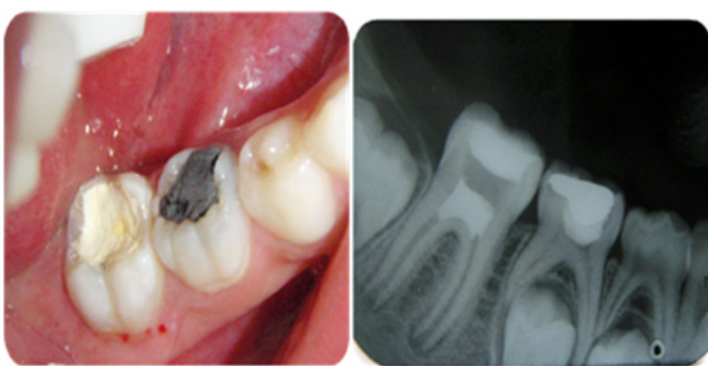

Figure 6I MTA barrier.

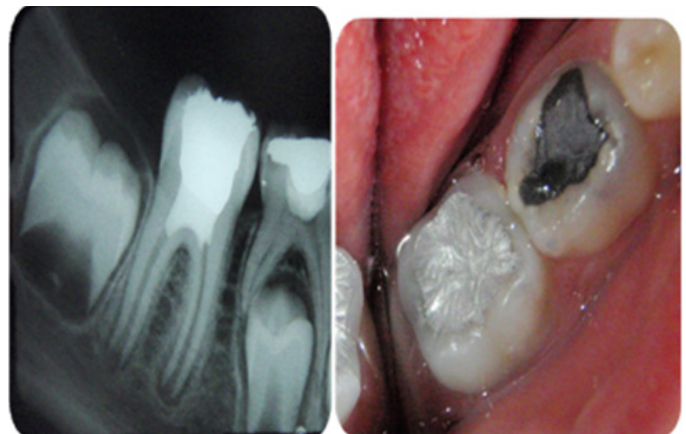

Figure 62 Final restoration.

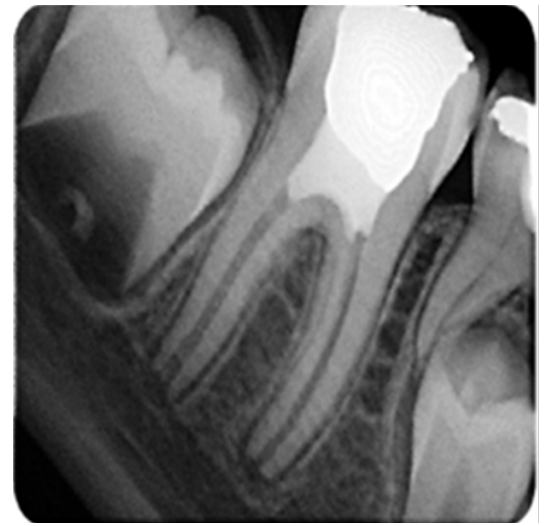

Figure 63 Four months later.

Before After
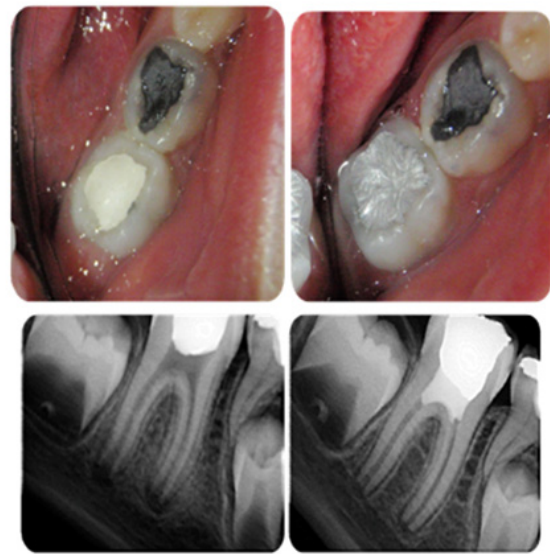

Figure 64 


\section{Discussion}

a. Favorable results were obtained concerning healing and root formation.

b. This might be due to ingrowth of cementum, dentin, or bonelike material.

c. Apical papilla is lacerated during bleeding step and represent a source of mesenchymal stem cells that delivered into the RC space.

\section{Lack of instrumentation}

a. Minimizes the potential fracture of these thin, incompletely developed roots.

b. Avoiding generation of a smear layer.

c. $\mathrm{NaOCl}$ and chlorhexidine in combination with triple antibiotic paste or $\mathrm{Ca}(\mathrm{OH}) 2$ disinfect the canal.

d. Laceration of apical papilla and apical tissues represents a rich source of mesenchymal stem cells.

e. A blood clot formed in the canal might serve as a protein (fibrin) scaffold, permitting three- dimensional ingrowth of tissue.

f. Growth factor comes from platelets and access to proteins embedded in the dentinal walls (Figure 65).

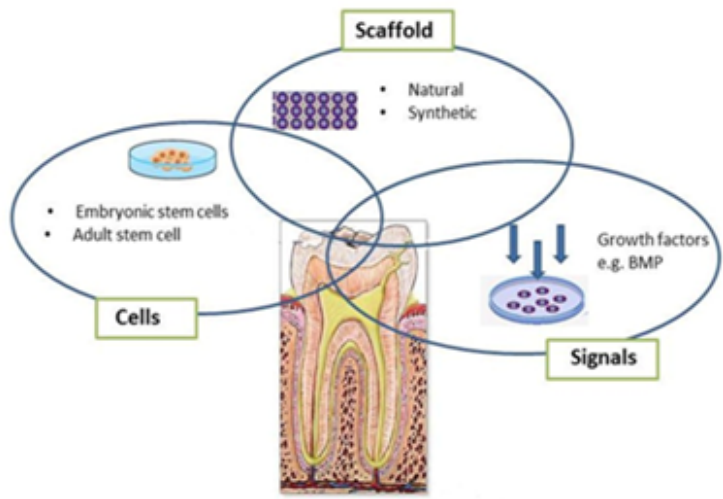

Figure 65

\section{Note}

a. Triple antibiotic paste produce greater wall thickness compared with $\mathrm{Ca}(\mathrm{OH}) 2$.

b. Placement of $\mathrm{Ca}(\mathrm{OH}) 2$ in coronal

c. Half of the RC increase the wall thickness (55\%) compare to placement in the apical half $(3 \%)$.

d. $\mathrm{Ca}(\mathrm{OH}) 2$ having a cytotoxic interaction with stem cells.

e. Minocycline causes staining of the crown. Use a delivery system to restrict the drug below the CEJ.

f. When it does occur, a walking bleach method with sodium perborate can be used (Figure 66 \& 67).

g. Most of the teeth gradually regained pulp sensibility and responded positively to EPT.

h. Although some teeth were non- responsive to pulp testing, vital tissue was identified in the apical root portion (Figure 68).

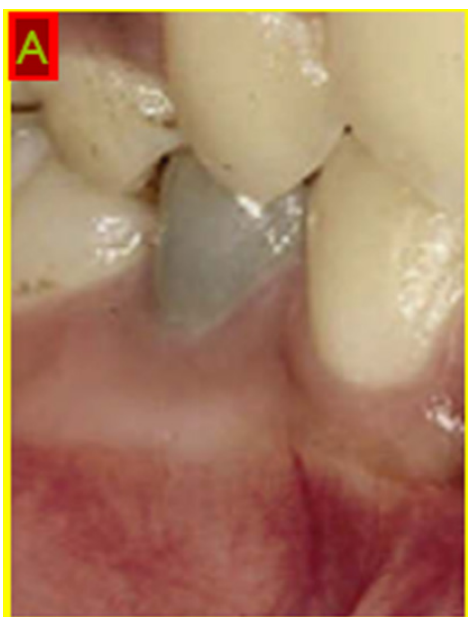

Figure 66 Photograph showing tooth discoloration.

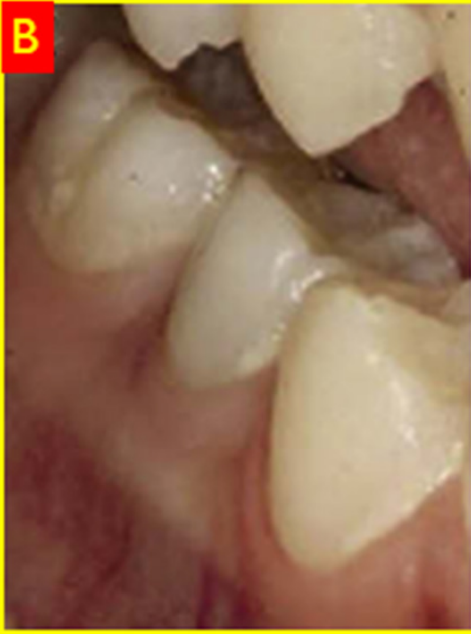

Figure 67 After bleaching.

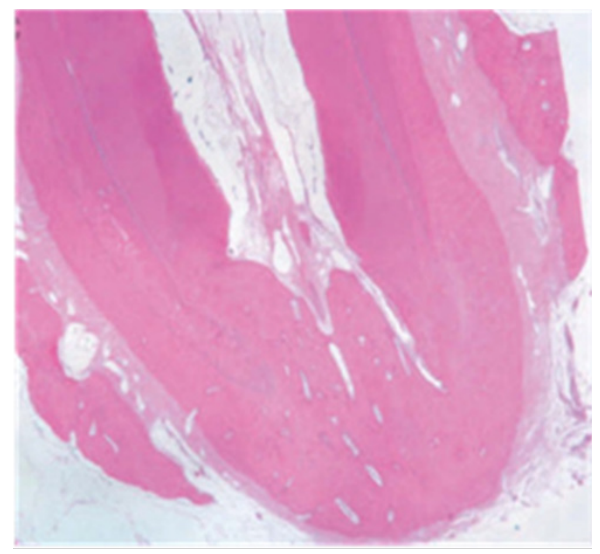

Figure 68 Thickened root walls, apical development, and healing of apica periodontitis in a dog tooth in where a periapical lesion had been created in an immature tooth (Thibodeau et al. J Endod, 1995).

\section{Measures of success for revascularization}

\section{Radiographically}

a. Healing of periradicular tissues. 

b. Continued root growth (in length and wall thickness).
c. Hitologically
d. Presence of vital tissue in the canal space.
e. Clinically
f. Asymptomatic tooth.
g. Response to pulp testing.
h. No need for retreatment.

\section{Advantages}
a. It requires a shorter treatment time.
b. Less cost.
c. Obturation of the canal is not required.

d. Danger of root splitting is minimized.

e. Continued root development is occurred.

\section{Conclusion}

It was concluded that this new technique do:

a. Regenerate stem cells/scaffolds/growth factors.

b. Regenerate the necrotic pulp of immature permanent teeth.

c. Maintain and restore the health of periradicular tissue.

\section{Acknowledgments}

None.

\section{Conflicts of interest}

The author declares there are no conflicts of interest. 